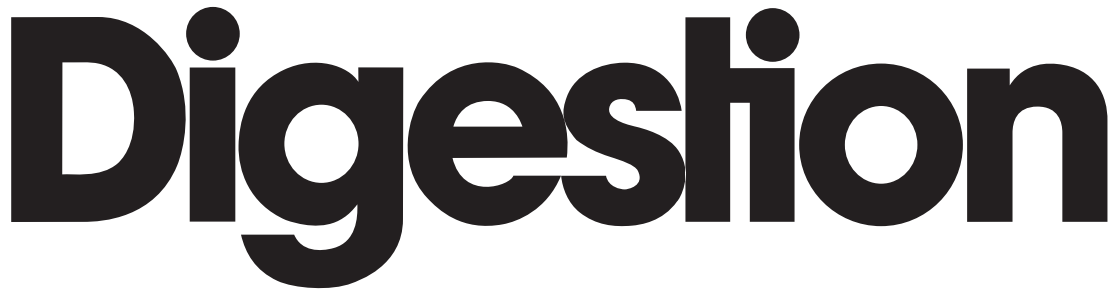

\title{
International Journal of Gastroenterology
}

Founded as 'Archiv für Verdauungskrankheiten' 1895 by I. Boas

Continued as 'Gastroenterologia' 1939-1967

Former Editors: P. Morawitz (1934-1936), R. Staehelin (1937-1943), A. Hurst (1940-1945),

W. Löffler (1943-1961), T.C. Hunt (1947-1967), N. Henning (1953-1962), B. Ihre (1953-1967),

H. Bartelheimer (1963-1967), M. Demole (1963-1971), H. Kapp (1968-1970),

R. Lambert (1972-1978), W. Creutzfeldt (1979-1992), R. Arnold (1993-2003)

\section{Editors-in-Chief}

C. Beglinger, Basel (Switzerland)

B. Göke, Munich (Germany)
Official Journal of

The Japanese

Gastroenterological Association (JGA)

\section{JGA Editorial Representatives}

Y. Kinoshita, Shimane

K. Higuchi, Osaka

\section{Associate Editors}

M. Delvaux, Nancy (France)

F. Kolligs, Munich (Germany)

G. Rogler, Zurich (Switzerland)

C. Rust, Munich (Germany)

R.M. Schmid, Munich (Germany)

Y. Shinomura, Sapporo (Japan)

K. Takeuchi, Kyoto (Japan) 
No. 1

Editorials

1 Granulocyte-Monocyte Apheresis - Not the End of the Road Yet!

Vavricka, S. (Zurich)

10 Pathogenesis of Strictures in Ulcerative Colitis: A Field to Explore Rogler, G. (Zurich)

36 Factors Attributing Hypoxemic Events during Upper-Gastrointestinal Endoscopy

Riphaus, A. (Bochum)

Original Papers

3 Effect and Safety of Granulocyte-Monocyte Adsorption Apheresis for Patients with Ulcerative Colitis Positive for Cytomegalovirus in Comparison with Immunosuppressants Yoshino, T.; Nakase, H.; Matsuura, M.; Matsumura, K.; Honzawa, Y. (Kyoto); Fukuchi, T.; Watanabe, K.; Murano, M. (Osaka); Tsujikawa, T. (Otsu); Fukunaga, K.; Matsumoto, T. (Nishinomiya); Chiba, T. (Kyoto)

12 Submucosal Fibrosis and Basic-Fibroblast Growth Factor-Positive Neutrophils Correlate with Colonic Stenosis in Cases of Ulcerative Colitis

Yamagata, M.; Mikami, T.; Tsuruta, T.; Yokoyama, K.; Sada, M.; Kobayashi, K.; Katsumata, T.; Koizumi, W.; Saigenji, K.; Okayasu, I. (Sagamihara)

22 Effect of Proton-Pump Inhibitor Therapy on Serum Chromogranin A Level

Pregun, I.; Herszényi, L.; Juhász, M.; Miheller, P.; Hritz, I.; Patócs, A.; Rácz, K.; Tulassay, Z. (Budapest)

29 Analysis of IL2/IL21 Gene Variants in Cholestatic Liver Diseases Reveals an Association with Primary Sclerosing Cholangitis

Stallhofer, J.; Denk, G.U. (Munich-Grosshadern); Glas, J.

(Munich-Grosshadern/Munich); Laubender, R.P.; Göke, B.; Rust, C.; Brand, S. (Munich-Grosshadern); Pusl, T. (Munich-Grosshadern/Augsburg)

37 Hypoxemia during Moderate Sedation for Gastrointestinal Endoscopy: Causes and Associations

Qadeer, M.A.; Lopez, A.R.; Dumot, J.A.; Vargo, J.J. (Cleveland, Ohio)

46 Proton Pump Inhibitor Dose-Related Healing Rate of Artificial Ulcers after Endoscopic Submucosal Dissection: A Prospective Randomized Controlled Trial

Kawano, S.; Okada, H.; Kawahara, Y.; Hori, K.; Tanioka, D.; Tsuzuki, T.; Inoue, M.; Yagi, S.; Takenaka, R.; Yamamoto, K. (Okayama)

54 Steroid and Ursodesoxycholic Acid Combination Therapy in Severe Drug-Induced Liver Injury

Wree, A.; Dechêne, A.; Herzer, K.; Hilgard, P. (Essen); Syn, W.-K. (Birmingham); Gerken, G.; Canbay, A. (Essen)

62 Serum Nitrate/Nitrite Concentration Correlates with Gastric Juice Nitrate/Nitrite: A Possible Marker for Mutagenesis of the Proximal Stomach

Kishikawa, H.; Nishida, J.; Ichikawa, H.; Kaida, S.; Matsukubo, T. (Chiba); Miura, S. (Saitama); Morishita, T. (Chiba); Hibi, T. (Tokyo)
70 Gastric Cancer Surveillance in a High-Risk Population in Tuscany (Central Italy): Preliminary Results

Filomena, A. (Borgo San Lorenzo); Saieva, C. (Florence); Lucchetti, V.; Santacroce, F.; Falorni, P.; Francini, V.; Carrieri, P. (Borgo San Lorenzo); Zini, E. (Florence); Ridolfi, B.; Belli, P. (Borgo San Lorenzo); Orsini, B. (Florence); Mandi, P. (Borgo San Lorenzo); Palli, D. (Florence); Scheggi, S. (Borgo San Lorenzo)

78 Prospective Randomized Comparison of Cold Snare Polypectomy and Conventional Polypectomy for Small Colorectal Polyps

Ichise, Y.; Horiuchi, A. (Komagane); Nakayama, Y.; Tanaka, N.

(Komagane/Matsumoto)

Letters to the Editor

60 Novel Endoscopic Technique for the Diagnosis of Early Gastric Cancer: Endoscopy with Crystal Violet Staining

Ohata, K.; Misaka, R.; Ito, T.; Chiba, H.; Tsuji, Y.; Yamawaki, M.; Ohya, T. (Tokyo); Inamori, M.; Nakajima, A. (Yokohama); Matsuhashi, N. (Tokyo)

82 Serum Neutrophil Gelatinase-Associated Lipocalin A Sensitive Novel Marker of Renal Impairment in Liver Cirrhosis?

Gerbes, A.L.; Benesic, A.; Vogeser, M. (Munich); Krag, A.; Bendtsen, F.; Møller, S. (Hvidovre)

84 JGA News

No. 2

Editorials

85 Nutrients and Gut Health Meier, R. (Liestal)

126 Prebiotics and Probiotics in Ulcerative Colitis: Where Do We Stand?

Rogler, G. (Zurich)

Reviews

89 Nutritional Modulation of the Inflammatory Bowel Response Ioannidis, O.; Varnalidis, I.; Paraskevas, G.; Botsios, D. (Thessaloniki)

102 Systematic Review of the Epidemiology of Complicated Peptic Ulcer Disease: Incidence, Recurrence, Risk Factors and Mortality

Lau, J.Y.; Sung, J. (Hong Kong); Hill, C.; Henderson, C. (Oxford); Howden, C.W. (Chicago, Ill.); Metz, D.C. (Philadelphia, Pa.)

Original Papers

114 Association between Left-Handedness and Gastrointestinal Symptoms

Fujiwara, Y.; Kubo, M.; Kohata, Y.; Yamagami, H.; Tanigawa, T.; Watanabe, K.; Watanabe, T.; Tominaga, K.; Arakawa, T. (Osaka)

\section{KARGER}

Fax +4161306 1234 E-Mail karger@karger.ch www.karger.com

\section{(c) 2011 S. Karger AG, Basel}

Access to full text and tables of contents, including tentative ones for forthcoming issues: www.karger.com/dig_issues 
119 Optimal Approach for Small Bowel Capsule Endoscopy Using Polyethylene Glycol and Metoclopramide with the Assistance of a Real-Time Viewer

Hosono, K.; Endo, H.; Sakai, E.; Sekino, Y.; Uchiyama, T.; Watanabe, S.; Iida, H.; Sakamoto, Y.; Koide, T.; Takahashi, H.; Yoneda, M.; Tokoro, C.;

Abe, Y.; Inamori, M.; Kobayashi, N.; Kubota, K.; Nakajima, A. (Yokohama)

128 Beneficial Effects of Probiotic Bifidobacterium and Galacto-Oligosaccharide in Patients with Ulcerative Colitis: A Randomized Controlled Study

Ishikawa, H. (Kyoto); Matsumoto, S.; Ohashi, Y.; Imaoka, A.; Setoyama, H.; Umesaki, Y.; Tanaka, R. (Tokyo); Otani, T. (Osaka)

134 High Hepatitis B Virus DNA Level in Serum before Liver Transplantation Increases the Risk of Hepatocellular Carcinoma Recurrence

Li, M.; Chen, G.; Cai, C.; Wang, G.; Zhao, H. (Guangzhou)

142 Survival Outcome Associated with the Screening Interval for Gastric Cancer in Korea

Lee, H.; Min, B.-H.; Lee, J.H.; Son, H.J.; Kim, J.J.; Rhee, J.C.; Kim, S.; Rhee, P.-L. (Seoul)

149 Carotid Intima-Media Thickness Is Increased Not Only in Non-Alcoholic Fatty Liver Disease Patients but Also in Alcoholic Fatty Liver Patients Kim, J.H.; Kim, S.Y.; Jung, E.S.; Jung, S.W.; Koo, J.S.; Kim, J.H.; Yeon, J.E.; Kwon, S.Y.; Lee, S.W.; Byun, K.S.; Lee, C.H. (Seoul)

156 Knock-Out of $\beta$-Glucosidase 2 Has No Influence on Dextran Sulfate Sodium-Induced Colitis

Scharl, M.; Leucht, K.; Frey-Wagner, I.; Zeitz, J.; Hausmann, M.; Fischbeck, A. (Zurich); Liebisch, G. (Regensburg); Kellermeier, S.; Pesch, T. Arikkat, J. (Zurich); Schmitz, G. (Regensburg); Fried, M. (Zurich); Yildiz, Y. (Bonn); Rogler, G. (Zurich)

\section{JGA News}

\section{No. 3}

Editorial

236 'Red Alert' or Not? - Do We Give Our Inflammatory Bowel Disease Patients the Right Dietary Recommendations? Rogler, G. (Zurich)

Review

212 Helicobacter pylori Infection and the Respiratory System: A Systematic Review of the Literature

Malfertheiner, M.V.; Kandulski, A.; Schreiber, J.; Malfertheiner, P. (Magdeburg)

Original Papers

169 Gene Expression following Exposure to Celecoxib in Humans: Pathways of Inflammation and Carcinogenesis Are Activated in Tumors but Not Normal Tissues

Sagiv, E. (Tel Aviv); Sheffer, M. (Rehovot); Kazanov, D.; Shapira, S.; Naumov, I.; Kraus, S. (Tel Aviv); Domany, E. (Rehovot); Arber, N. (Tel Aviv)

187 Low Risk of Clostridium difficile Infections in Hospitalized Patients with Inflammatory Bowel Disease in a German Tertiary Referral Center

Ott, C.; Girlich, C.; Klebl, F.; Plentz, A.; Iesalnieks, I.; Schölmerich, J. Obermeier, F. (Regensburg)

193 Capnographic Monitoring during Endoscopic Submucosal Dissection with Patients under Deep Sedation: A Prospective, Crossover Trial of Air and Carbon Dioxide Insufflations Takano, A.; Kobayashi, M.; Takeuchi, M.; Hashimoto, S.; Mizuno, K.; Narisawa, R.; Aoyagi, Y. (Niigata)
199 Evaluation of Performance of Measurement of Faecal $\alpha_{1}$-Antitrypsin Clearance and Technetium-99m Human Serum Albumin Scintigraphy in Protein-Losing Enteropathy Chau, T.N.; Mok, M.Y.; Chan, E.Y.T.; Luk, W.H.; Lai, K.B.; Li, F.T.W.; Leung, V.K.S. (Hong Kong); Wong, R. (Brisbane, Qld.)

207 Single-Photon Emission Computed Tomography Enhanced Tc-99m-Pertechnetate Disodium-Labelled Red Blood Cell Scintigraphy in the Localization of Small Intestine Bleeding: A Single-Centre Twelve-Year Study Dolezal, J.; Vizda, J.; Kopacova, M. (Hradec Kralove)

221 Healing Effects of Rebamipide and Omeprazole in Helicobacter pylori-Positive Gastric Ulcer Patients after Eradication Therapy: A Randomized Double-Blind, Multinational, Multi-Institutional Comparative Study Song, K.H. (Daejeon); Lee, Y.C. (Seoul); Fan, D.-M. (Xian); Ge, Z.-Z. (Shanghai); Ji, F. (Hangzhou); Chen, M.-H. (Guangzhou); Jung, H.C. (Seoul); Bo, J. (Guangzhou); Lee, S.W.; Kim, J.-H. (Seoul)

230 Effect of Low-Dose Gemcitabine on Unresectable Pancreatic Cancer in Elderly Patients

Matsumoto, K. (Okayama/Kanonji); Miyake, Y.; Kato, H.; Kawamoto, H. (Okayama); Imagawa, A.; Toyokawa, T.; Nakatsu, M.; Ando, M.; Hirohata, M. (Kanonji); Yamamoto, K. (Okayama)

238 Is Moderate Red Wine Consumption Safe in Inactive Inflammatory Bowel Disease?

Swanson, G.R.; Tieu, V.; Shaikh, M.; Forsyth, C.; Keshavarzian, A. (Chicago, Ill.)

247 Evidence for Altered Anorectal Function in Irritable Bowel Syndrome Patients with Sleep Disturbance Chen, C.-L.; Liu, T.-T.; Yi, C.-H. (Hualien); Orr, W.C. (Oklahoma City, Okla.) Letters to the Editor

185 The Missing Link between Obesity and Hepatocellular Carcinoma: IL-6-Mediated STAT-3 Activation as a Key Player in Hepatocarcinogenesis

Beyazit, Y.; Sayilir, A.; Suvak, B.; Torun, S. (Ankara)

245 Trainee Participation during Colonoscopy Adversely Affects Polyp and Adenoma Detection Rates Nishizawa, T.; Suzuki, H.; Takahashi, M.; Kaneko, H.; Fujiyama, Y.; Komatsu, H.; Nagumo, H.; Tanaka, S.; Hibi, T. (Tokyo)

252 JGA News

\begin{tabular}{ll} 
No. 4 \\
Editorials \\
\hline I & $\begin{array}{l}\text { Editorial } \\
\text { Beglinger, C. (Basel) }\end{array}$ \\
$321 \begin{array}{l}\text { Eosinophilic Esophagitis: From a Sneaking Suspicion to a } \\
\text { Clear Diagnosis }\end{array}$ \\
Straumann, A. (Basel) \\
$\quad$ Original Papers \\
\hline $253 \begin{array}{l}\text { Usefulness of a Slow Nutrient Drinking Test for Evaluating } \\
\text { Gastric Perception and Accommodation }\end{array}$ \\
Iida, A. (Nagakute); Konagaya, T.; Kaneko, H. (Nagoya); Funaki, Y.; \\
Kanazawa, T.; Tokudome, K.; Hijikata, Y.; Masui, R.; Ogasawara, N.; \\
Sasaki, M.; Yoneda, M.; Kasugai, K. (Nagakute)
\end{tabular}

261 A Long-Term Study of Acotiamide in Patients with Functional Dyspepsia: Results from an Open-Label Phase III Trial in Japan on Efficacy, Safety and Pattern of Administration Matsueda, K. (Tokyo); Hongo, M. (Sendai); Ushijima, S.; Akiho, H. (Tokyo)

269 Fructose Malabsorption: How Much Fructose Can a Healthy Subject Tolerate?

Frieling, T.; Kuhlbusch-Zicklam, R.; Kalde, S.; Heise, J.; Hülsdonk, A.; Kreysel, C. (Krefeld) 
273 The Evaluation of Oesophageal Function in Patients with Different Types of Oesophageal Metaplasia

Rosztóczy, A.; Izbéki, F.; Róka, R.; Németh, I.; Gecse, K.; Vadászi, K.; Kádár, J.; Vetró, É.; Tiszlavicz, L.; Wittmann, T. (Szeged)

281 Opportunistic Screening of Hospital Staff Using Primary Colonoscopy: Participation, Discomfort and Willingness to Repeat the Procedure

Khalid-de Bakker, C.A.; Jonkers, D.M.; Hameeteman, W.; de Ridder, R.J.; Masclee, A.A.; Stockbrügger, R.W. (Maastricht)

289 Improvement of Non-Steroidal Anti-Inflammatory Drug-Induced Gastrointestinal Symptoms during Proton Pump Inhibitor Treatment: Are G-Protein $\beta 3$ Subunit Genotype, Helicobacter pylori Status, and Environmental Factors Response Modifiers?

Holtmann, G. (Woolloongabba, Qld./Adelaide, S.A.); van Rensburg, C (Cape Town); Schwan, T.; Sander, P. (Konstanz); Siffert, W. (Essen)

299 Gastric Wash-Based Molecular Testing for Antibiotic Resistance in Helicobacter pylori

Baba, S.; Oishi, Y.; Watanabe, Y.; Oikawa, R.; Morita, R.; Yoshida, Y.; Hiraishi, T.; Maehata, T.; Nagase, Y.; Fukuda, Y.; Nakazawa, M.; Ishigouoka, S.; Hattori, N. (Kawasaki); Suzuki, H.; Toyota, M. (Sapporo); Niwa, H.; Suzuki, M.; Itoh, F. (Kawasaki)
306 Capsule-Endoscopic Findings of Ulcerative Colitis Patients Higurashi, T.; Endo, H.; Yoneda, M.; Hosono, K.; Sakai, E.; Takahashi, H.; Inamori, M.; Uchiyama, S.; Kojima, T.; Kawana, K.; Natsumeda, Y, Nagase, H.; Nakajima, A. (Yokohama)

315 Proton Pump Inhibitors versus Histamine-2-Receptor Antagonists for the Management of latrogenic Gastric Ulcer after Endoscopic Mucosal Resection or Endoscopic Submucosal Dissection: A Meta-Analysis of Randomized Trials Yang, Z.; Wu, Q.; Liu, Z.; Wu, K.; Fan, D. (Xi’an)

323 Identification of Clinical and Laboratory Markers for Predicting Eosinophilic Esophagitis in Adults von Arnim, U.; Wex, T.; Röhl, F.-W.; Neumann, H.; Küster, D.; Weigt, J.; Mönkemüller, K.; Malfertheiner, P. (Magdeburg)

328 JGA News

329 Acknowledgement to Referees
S. Karger

Medical and Scientific Publishers

Basel $\bullet$ Freiburg $\bullet$ Paris $\cdot$ London $\cdot$ New York

New Delhi $\bullet$ Bangkok $•$ Beijing $•$ Tokyo

Kuala Lumpur $\cdot$ Singapore $\cdot$ Sydney
Disclaimer

The statements, opinions and data contained in this publication are solely those of the individual authors and contributors and not of the publisher and the editor(s). The appearance of advertisements in the journal is not a warranty, endorsement or approval of the products or services advertised or of thei effectiveness, quality or safety. The publisher and the editor(s) disclaim responsibility for any injury to persons or property resulting from any ideas, methods, instructions or product referred to in the content or advertisements.

Drug Dosage

The authors and the publisher have exerted every effort to ensure that drug selection and dosage set forth in this text are in accord with current recommendations and practice at the time of publication. However, in view of ongoing research, changes in government regulations, and the constant flow of information relating to drug therapy and drug reactions, the reader is urged to check the package insert for each drug for any change in indications and dosage and for added warnings and precautions. This is particularly important when the recommended agent is a new and/or infrequently employed drug.
All rights reserved.

No part of this publication may be translated into other languages, reproduced or utilized in any form or by any means, electronic or mechanical, including photocopying, recording, microcopying, or by any information storage and retrieval system, without permission in writing from the publisher or, in the case of photocopying, direct payment of a specified fee to the Copyright Clearance Center (see 'General Information').

(c) Copyright 2011 by S. Karger AG

P.O. Box, CH-4009 Basel (Switzerland) Printed in Switzerland

on acid-free and non-aging paper (ISO 9706) by

Reinhardt Druck, Basel 